\title{
Making a Federal Case: Youth Groups, Students and the 1975 European Economic Community Referendum Campaign to Keep Britain in Europe.
}

\section{Stuart Smedley, King's College London}

\section{Abstract}

To persuade the electorate to vote 'Yes' in the June 1975 referendum on the United Kingdom's membership of the European Economic Community, Britain in Europe, the proEuropean campaign organisation, adopted a pragmatic approach, focusing on the economic benefits of membership and warning about the potentially grave consequences of withdrawal. Importantly, they avoided discussing proposed future advances in European integration. However, this theme was of importance to pro-European youth and student campaign groups - the subject of this paper. Through a detailed analysis of their campaign literature, this article further transforms understanding of the 1975 referendum and, especially, the nature of the 'Yes' campaign by demonstrating how radical youth groups' arguments for continued membership were. It argues that young activists yearned to discuss sovereignty and deeper integration in great detail as they offered idealistic visions for how the EEC could develop and benefit Britain. The article also advances knowledge of youth politics in the turbulent 1970s. Greater light is shone on the frustration pro-European youth groups felt towards the main Britain in Europe campaign. Meanwhile, it serves as a case study on the extent to which the perspectives of party-political youth groups and their superiors differed on a specific, highly salient policy issue.

Key words: Britain and Europe, 1975 EEC referendum, European integration, Student politics, Youth politics 


\section{Introduction}

For decades the historical record of the June 1975 referendum on the United Kingdom's membership of the European Economic Community (EEC) was largely limited to a trio of books published in the vote's immediate aftermath. These were thorough in their examination of the decision to hold the first nationwide plebiscite in the UK's history, the referendum campaign and its outcome - a vote in favour of continued membership by a two-thirds majority. ${ }^{1}$ However, they were unable to draw upon official papers belonging to the two main campaign organisations - Britain in Europe (BIE) and the anti-Common Market National Referendum Campaign (NRC) - as well as the government's Referendum Steering Group. Finally helping to fill that significant gap forty-three years on was Robert Saunders's comprehensive account of the 1975 vote. ${ }^{2}$ His book, published two years after the June 2016 referendum which saw the UK electorate narrowly vote in favour of leaving the European Union, was a timely addition to the literature. Utilising an extensive assortment of archival sources, Saunders, as he describes his efforts, 'uses the referendum as a window into the political and social history of the $1970 \mathrm{~s}^{\prime} .^{3}$ His work brings to life one of the most significant milestones in the history of Britain's relationship with Europe, detailing not only the arguments and activities of the politicians campaigning on either side, but also the views

\footnotetext{
${ }^{1}$ See David Butler and Uwe Kitzinger, The 1975 Referendum, (Basingstoke, 1976); Anthony King, Britain Says Yes: The 1975 Referendum on the Common Market (Washington DC, 1977); and Philip Goodhart, Full-Hearted Consent: The Story of the Referendum Campaign and the Campaign for the Referendum (London, 1976). Relying primarily on interview data, Butler and Kitzinger's work analyses the campaigns, as well as reviewing broadcasting, newspapers and opinion polls. King, a social scientist, concentrates largely upon similar themes, while Goodhart, a then-Conservative Member of Parliament, provides a Westminster insider's account of the referendum.

${ }^{2}$ Robert Saunders, Yes to Europe! The 1975 Referendum and Seventies Britain (Cambridge, 2018).

${ }^{3}$ Saunders, Yes to Europe!, 23
} 
of a diverse range of actors, including women, employers, trade unionists, religious organisations and regional political parties.

However, one fascinating group of the electorate - pro-European student and youth groups - have still not received significant scholarly attention. In their account of the referendum David Butler and Uwe Kitzinger describe them in passing as possessing a uniquely 'federalist zeal'. ${ }^{4}$ Saunders, meanwhile, notes their 'energy and humour' and the feelings of frustration they felt towards the 'uninspiring tone' and risk-averse nature of BIE's main campaign. ${ }^{5} \mathrm{He}$ also provides brief descriptions of some of their eye-catching campaign activities. ${ }^{6}$ Yet absent from both is a thorough examination of the arguments youth groups put forward as to why Britain should remain a member of the EEC. Butler and Kitzinger's remark alone begs the question as to just how radical their ideas were. Furthermore, a large amount of archival material is available to investigate their views.

By reviewing such material, this article presents a detailed analysis of the contributions of pro-European youth groups to the 1975 referendum debate. The first of five sections scrutinises cross-party youth organisations, describing their campaign activities and comparing their optimistic justifications for why Britain should continue with its membership of the EEC with the transactional, at times fear-inducing perspective offered by the main BIE campaign. Next, Conservative youth organisations' literature, which stuck largely to the party line, is assessed. The subsequent two sections review material produced by groups belonging to the Labour and Liberal parties, whose publications, in contrast to

\footnotetext{
${ }^{4}$ Butler and Kitzinger, The 1975 Referendum, 82.

${ }^{5}$ Saunders, Yes to Europe!, 108-10.

${ }^{6}$ Saunders, Yes to Europe!, 127-8.
} 
Conservative youth groups, were far more radical in tone and willing to challenge the arguments put forward by the senior parties. The final section analyses The Federalist, a magazine produced by members of BIE's Youth Steering Group, whose views of the EEC and what it could become were remarkable.

Through this analysis, the article further transforms understanding of the 1975 referendum, building on Saunders's recent work. It demonstrates that there were groups in favour of membership who yearned to discuss sovereignty and European integration in great depth. The often idealistic arguments that the various student and youth organisations made were striking in content and tone too. Though seeing European integration as a means to serve differing ends, those fighting for Britain to retain its place as a member of 'The Nine' all sought to put forward the case for establishing deeper ties with the Community. Meanwhile, they possessed a desire to present ideas about the future direction of integration that their cautious superiors lacked. Furthermore, in certain cases, their arguments were rather prescient, foretelling advances in integration. More broadly, reviewing their contributions sheds further light on the less widely researched field of youth politics in the 1970s, enhancing knowledge of the relationship between party-political youth groups and their elders, while also showcasing youth perspectives on a specific, highly salient policy issue. ${ }^{7}$

\footnotetext{
${ }^{7}$ Despite the notoriety certain youth campaign groups attained in this period, they have received little academic attention. In the 1970s Zig Layton-Henry published contemporary accounts charting the history of the Conservative and Labour parties' youth organisations. See Zig Layton-Henry, 'The Young Conservatives, 1945-1970', Journal of Contemporary History, 8 (1973) and Zig Layton-Henry, 'Labour's Lost Youth', Journal of Contemporary History, 11 (1976).

In more recent decades, there has been some interest in the Young Conservative movement and Labour's various youth groups. See John Holroyd-Doveton, Young Conservatives: A History of the Young Conservative
} 
Overall, by going beyond the main Britain in Europe campaign literature and analysing that of pro-European youth organisations, it become clears that a passionately argued, federalist case for EEC membership was made. However, young activists' arguments gained little traction in the face of BIE's smothering, risk-averse approach.

\section{Cross-party youth groups}

The cross-party nature of the main Britain in Europe campaign was very effective, with leading politicians from the Labour, Conservative and Liberal parties working cohesively with one another. ${ }^{8}$ Yet despite this, the arguments they made to persuade the electorate to vote 'Yes' were rather uninspiring. In contrast, youth campaigners from across the political spectrum proved harder to bring together. Nevertheless, the material they published, while touching on many similar themes to that of the senior BIE campaign, was much more optimistic in tone and hinted at the radical, idealistic views many young pro-European activists held.

Movement (Bishop Auckland, 1996) and Michelle Webb, The Labour League of Youth: An Account of the Failure of the Labour Party to Sustain a Successful Youth Organisation (Lewiston, New York, 2010). Meanwhile, Catherine Ellis provides an account of Young Conservative opinions on a particular policy area. See Catherine Ellis, 'No Hammock for the Idle: The Conservative Party, 'Youth' and the Welfare State in the 1960s', Twentieth Century British History, 16, 4 (2005).

Histories related to the Young Liberals, whose role in protests against Apartheid and the Vietnam War received significantly publicity in the late 1960s and early 1970s, are primarily limited to publication in journals dedicated to the Liberal Party's history. See Peter Hellyer, 'Young Liberals: The 'Red Guard' Era', Journal of Liberal Democrat History, 17 (1997) and Peter Hellyer, 'The Young Liberals and the Left, 1965-70', Journal of Liberal History, 67 (2010).

${ }^{8}$ Butler and Kitzinger, The 1975 Referendum, 96; Goodhart, Full-Hearted Consent, 187; King, Britain Says Yes, 108. 
To try and replicate the harmonious cross-party efforts at a youth level, BIE established a Youth Steering Group. Headed by Archy Kirkwood, an aide to Liberal MP David Steel, and with Tom Spencer, personal assistant to BIE Director Sir Con O'Neill, also playing a leadership role, this was a small-scale body, with a single representative from each of the main party youth organisations as well as Students for a United Europe (SUE) and the Young European Federalists (YEF). ${ }^{9}$ SUE and YEF were notionally cross-party organisations. But their membership was dominated by Conservative supporters, with both having a smattering of Labour members who generally held leadership positions. ${ }^{10}$ The aim of the Steering Group was to coordinate youth campaign activities and, in O'Neill's words, to ensure that these demonstrated 'unity in diversity'. ${ }^{11}$ The Youth Steering Group was initially assigned a budget of $£ 15,000$, though this was increased during the campaign to $f 19,465-a$ fraction of the near $£ 2$ million that BIE raised. ${ }^{12}$ This was used to fund national and local youth activities, whose effectiveness was questionable.

\footnotetext{
${ }^{9}$ SUE formed in 1972 as the student section of the European Movement, the independent, pro-European campaign group. Two years later, YEF was established, becoming the 'formal British member of Jeunesse
} Européene Fédéraliste', an international youth organisation aimed at promoting European integration. See PA, BIE/1/83, 'Memo from Tom Spencer to Sir Con O’Neill, “The Plain Man’s Guide to the European Youth Organisations"' 19 February 1975.

${ }^{10}$ Author interview with Piers Gardener, 3 August 2012.

${ }^{11}$ PA, BIE/27/2, 'Memo from Sir Con O’Neill to Heads of Department', 1 April 1975.

${ }^{12} \mathrm{PA}, \mathrm{BIE} / 28 / 2$. According to BIE accounts, it appears that $£ 2,000$ allocated to the youth campaign went unspent.

Money was also made available to youth groups through the budgets BIE gave to the political parties. However, any allocations were at the discretion of the parties. For instance, of the $£ 140,000$ the Conservatives received from BIE, $£ 13,000$ was distributed to the Young Conservatives and Federation of Conservative Students. See PA, BIE/28/2, 'Conservative Party Budget: $1^{\text {st }}$ April-6 $6^{\text {th }}$ June 1975 '. For more on BIE's finances, see Butler and Kitzinger, The 1975 Referendum, 86; and Saunders, Yes to Europe!, 108. 
At a national level, three main youth campaign events were organised, beginning with a Torchlight Procession on 29 April and ending with an eve of poll vigil in Parliament Square, the latter of which was attended by former Prime Minister Harold Macmillan. In between, on 4 May a Youth Rally was held in Trafalgar Square featuring Edward Heath, David Steel, Education Secretary Reg Prentice, and trade unionist Roy Grantham, as well as representatives of the Young European Left and Young Conservative youth groups, as speakers. The rally attracted a crowd of over $3,000 .{ }^{13}$ However, the event did not pass without controversy. Two days prior, Young Liberal president Peter Hain withdrew, alleging he had been told to 'be "selective" in his remarks', an instruction seen as an attempt to stifle the 'distinctiveness of the Liberal pro-Europe campaign'. ${ }^{14}$ YEF chairman Anthony Speaight also reported he had been told he could not speak, and took to the Daily Telegraph to suggest BIE were "'putting the drapes" over the radical youth campaigns' of organisations like his. ${ }^{15}$

The most unique activity the Youth Steering Group organised was its 'Youth Aid' scheme, which saw young activists from other EEC member states as well as Sweden and Norway participate in campaign efforts. Around thirty took part and were assigned to regional BIE groups. However, demonstrating the tension between the youth and senior campaigns, this scheme was sanctioned by the latter 'subject to stringent safeguards on the recruitment, briefing and control of volunteers' ${ }^{16}$ Additionally, the number of participants was lower than anticipated, with those who did travel strictly briefed as to what they could

\footnotetext{
13 'Mr Heath urges poll opponents to say “yes"', The Times, 5 May 1975, 4.

${ }^{14}$ LSE/Young Liberals/Box 4, 'Draft Press Release - EEC Speech Censored', 2 May 1975.

15 'Heath outshouts hecklers', Daily Telegraph, 5 May 1975.

${ }^{16}$ PA, BIE/1/72, 'Minutes of Referendum Steering Group meeting', 12 March 1975.
} 
say. ${ }^{17}$ Meanwhile, hinting at the failure of the Youth Steering Group to successfully coordinate activities between party-political organisations, the Young Liberals organised their own scheme. However, this was most notable for having only four participants from other member states, two of whom turned out to be anti-Marketeers. ${ }^{18}$

The success of national youth campaign events was therefore mixed, with tensions and a lack of coordination between the various youth groups a common theme. Despite the aforementioned close ties between the leadership of the Youth Steering Group and senior BIE figures, frustration grew thanks to their superiors' apparent desire to control the youth message and limit the exposure young activists received. Although BIE granted a concession in the form of a dedicated youth press conference just over a week before the referendum, this did not fully assuage the youth campaign arm's unhappiness. ${ }^{19}$ Revolt stewed, and the Youth Steering Group organised an occupation of BIE's headquarters. ${ }^{20}$

That disorganisation, disquiet with their superiors and a touch of rebellion were features of their activities was arguably little surprise. But it is from youth campaign literature that more interesting conclusions can be drawn. Money allocated to the Youth Steering Group was used to fund the publication of this material, whose content was revealing not only for what it said about the relationship between the senior and youth

\footnotetext{
${ }_{17}$ PA, BIE/27/6, 'Youth Aid Scheme Account' 25 May 1975 and 'Letter from Hilaire Eustace', 1 May 1975.

18 LSE, Young Liberals/Box 3, 'Letter from Simon Hebditch to Colin Deans', 28 May 1975.

${ }^{19} \mathrm{PA}, \mathrm{BIE} / 28 / 1$, 'Notes on a meeting with Youth Representatives', 21 May 1975 and 'Minutes of Executive Committee pre-Press Conference Meetings', 22 May 1975. The press conference allocated to the Youth Steering Group took place on Monday 26 May - a bank holiday - and was chaired by David Steel.

${ }^{20}$ PA, BIE/27/2, 'Youth Revolt: The Next Stages'.
} 
campaigns, but also the way in which those involved with cross-party groups saw European integration.

As important as detailed polling was to honing their messages, the main BIE campaign has been unable to escape from the contention that the arguments they expressed in favour of continued membership concentrated on 'mundane issues' ${ }^{21}$ BIE are noted too for framing the choice at the hands of the electorate as if 'there was simply no alternative' ${ }^{22}$ Subsequently, Eurosceptic voices protested that BIE disregarded discussions of sovereignty, plans for deeper integration and proposals to move towards a 'federal Europe'. ${ }^{23}$ Yet while sovereignty did feature, BIE had set out arguments to avoid early in their planning. ${ }^{24}$ Importantly, the debate would not, 'except in response to manifest demand', 'centre on the future institutional development of the Community' or its 'structure and working'. In particular it was felt that the public would regard the latter as 'boring and unpersuasive'. ${ }^{25}$ Instead, BIE determined their case would focus on the economic benefits of membership relating to jobs, the security of Britain's food supply and the nation's future prosperity - all salient issues at a time of high inflation, economic stagnation and industrial unrest. Other themes of emphasis included Commonwealth support for Britain's continued membership; the EEC's contribution to preserving peace; the

\footnotetext{
${ }^{21}$ Stephen George, An Awkward Partner: Britain in the European Community, $3^{\text {rd }}$ edition (Oxford, 1998$), 24$.

22 John W. Young, Britain and European Unity, 1945-1999, $2^{\text {nd }}$ edition (Basingstoke, 2000), 119.

${ }^{23}$ Saunders, Yes to Europe!, 232-3.

${ }^{24}$ Sovereignty played only a minor role in the government's official publication, Britain's New Deal in Europe, copies of which, alongside BIE and NRC pamphlets, were delivered to British households in May 1975. Instead, a key feature of the government's document was its 'negative arguments against the risks of leaving the EC'.' See Lindsay Aqui, 'Government policy and propaganda in the 1975 referendum on European Community membership', Contemporary British History (2019), DOI: 10.1080/13619462.2019.1588115.

${ }^{25}$ PA, BIE/1/74, 'Illustrative Policy Guidance', 27 January 1975.
} 
lack of alternatives for Britain; and the 'No' campaign's distorted claims. ${ }^{26}$ This translated into BIE adopting defensive arguments in their official pamphlet, while their campaign posters emphasised the transactional benefits of membership and featured fearful messages aimed at specific groups. ${ }^{27}$

In contrast to BIE's sometimes doom-laden tone, cross-party youth organisations deployed more optimistic arguments for remaining an EEC member. Nevertheless, while they did seek to promote the benefits of a future federal Europe, some of their literature possessed a pragmatic, apolitical air. Most notable was the desire to portray EEC membership as something that offered a brighter future to younger generations.

Differences were evident when comparing SUE and YEF's referendum literature though. The more overtly political YEF put forward strong federalist arguments. Indeed, their primary campaign leaflet did not hold back in emphasising these credentials, its opening paragraph stating:

The European Community provides a framework for the creation of a democratic Federation in Europe ... Powers in such a Federation should be distributed between European, national and regional governments. ${ }^{28}$

According to YEF, national governments were unable to deal with certain issues in an age marked by the liberalisation of trade, the existence of multinational companies and the

\footnotetext{
${ }^{26} \mathrm{PA}, \mathrm{BIE} / 1 / 75$, 'Britain in Europe Statement (Draft)', undated.

${ }^{27}$ The main text of Britain in Europe's official leaflet is reproduced in Butler and Kitzinger's book. See Britain in Europe, 'Why You Should Vote Yes' in Butler and Kitzinger, The 1975 Referendum, 291-4. For poster designs see $\mathrm{PA}, \mathrm{BIE} / 18 / 17-20$.

${ }^{28}$ PA, BIE/15/1, 'Young European Federalists'.
} 
nuclear bomb. Sovereignty, they argued, was little more than 'an illusion'. As a result, this situation necessitated a 'common political authority' operating within a tiered federation. Changes in the way the EEC functioned were required. The Community needed to drop its 'obsession with harmonisation' and instead rectify the 'grave regional imbalances' that existed, ahead of introducing a common currency. On top of this, YEF urged the EEC to provide greater support to the world's developing countries, establish a directly elected Parliament and abolish the national veto. ${ }^{29}$

In contrast, SUE adopted a tone whose ideological commitment to European integration was less potent. Instead, their arguments for remaining a member mirrored some of those of the main BIE campaign, albeit with a more positive spin attached to a rather pragmatic case. The group's key message was 'Build Bridges - Not Barriers', with its main leaflet depicting a bridge spanning the English Channel, symbolically connecting Britain to continental Europe. For SUE, the EEC was capable of eliminating 'old prejudices which have prevented international cooperation in the past', better equipped than individual governments to stand up to multinational companies and capable of providing greater assistance to developing countries. Overall, Common Market membership improved 'our prosperity, our employment, our environment and the way Britain faces up to the future' ${ }^{30}$ Other material was directed at a more specific audience. One SUE poster sought to convince those on the left that the EEC was not a capitalist conspiracy by pointing out that socialist parties in other member states all wanted Britain to continue its membership. ${ }^{31}$ In addition to trying to persuade supporters of a Labour Party backing withdrawal, this was perhaps

\footnotetext{
${ }^{29} \mathrm{PA}, \mathrm{BIE} / 15 / 1$, 'Young European Federalists'.

$30 \mathrm{PA}, \mathrm{BIE} / 2 / 7$, 'Students for a United Europe, YES! Britain is where she belongs ... in Europe'.

${ }^{31} \mathrm{PA}, \mathrm{BIE} / 18 / 23$, 'Students for a United Europe, 40 Million Socialists Want Britain to Stay in Europe'.
} 
recognition of the need to reach out to those on the other side of the ideological divide from a group conscious of its Conservative-dominated membership.

SUE and YEF material also stressed that the EEC contributed to the preservation of peace. The youth organisations mass produced labels depicting a poppy accompanied by the message: 'Remembrance Day, it's what Europe's about', while YEF published a poster stating: '1914-1918, 1939-1945, NATIONALISM Kills. No more Civil Wars. Vote Yes.'32 Peace had been a key theme for the main BIE campaign too. Yet its message was put across in more macabre fashion. One poster design bore the startling message: 'Better lose a little national sovereignty than a son or daughter'.$^{33}$

Another common argument cross-party youth groups and the senior BIE campaign sought to express was that the anti-Marketeers represented untrustworthy, sometimes extremist individuals and organisations. BIE produced a number of posters that simply listed those backing continued membership and those who favoured Britain's withdrawal. To the latter category belonged the National Front, Communist Party of Great Britain and Irish Republican Army, with voters implored 'to decide who you stand beside' ${ }^{34}$ Another design gave a long list of countries, including fellow EEC and Commonwealth members and the United States of America, described as 'Friends who say yes', with just Russia beneath the heading 'Friends who say no'. ${ }^{35}$ Clearly the messages were that a 'No' vote would embolden those who threatened democracy and social harmony, as well as the West's primary Cold War adversary. Youth organisations produced similar material. But they directed their

\footnotetext{
${ }^{32} \mathrm{PA}, \mathrm{BIE} / 18 / 23$ and $\mathrm{BIE} / 27 / 7$.

${ }^{33} \mathrm{PA}, \mathrm{BIE} / 18 / 19$; Saunders, Yes to Europe!, 46.

${ }^{34} \mathrm{PA}, \mathrm{BIE} / 18 / 17$.

$35 \mathrm{PA}, \mathrm{BIE} / 18 / 20$.
} 
literature towards student groups, listing the National Union of Students Executive, who had successfully passed a motion to campaign for withdrawal, as extremists alongside the National Front and Communist Party. ${ }^{36}$ Rarely though did the senior campaign use posters to target prominent anti-Marketeers. Instead, they relied on newspaper columns and television appearances, platforms where a more sophisticated critique of their opponents' arguments, rather than attacks on their personalities, could be made. ${ }^{37}$ Youth groups, however, were not reluctant to target the personalities of prominent anti-Marketeers using posters. One SUE design attacked Enoch Powell, accusing him of racism and hysteria, while also mocking his claims about sovereignty being destroyed as deceitful given his previous doom-laden predictions about the impact of Commonwealth and Irish immigration. ${ }^{38}$

Cross-party youth organisations also deployed posters with apolitical messages implying that being an EEC member - and European - was something trendy. Designs contained optimistic, yet bland messages such as 'Europe means a Great Deal to the Young' and 'Young Europeans: Simply A Generation Ahead'. The latter included a picture of four

\footnotetext{
${ }^{36} \mathrm{PA}, \mathrm{BIE} / 18 / 25$. The NUS President at the time was Charles Clarke, who considered himself 'a Marxist to the left of Mr Benn'. Yet it is highly questionable as to whether the politics of the NUS reflected that of the wider student-body, whose attitudes are described as having been 'surprisingly conservative'. See Dominic Sandbrook, Seasons in the Sun: The Battle for Britain, 1974-1979 (London, 2012), 296-8.

The NUS's stance certainly did not reflect opinion among those active in the Oxford Union, the launchpad for many prominent political careers. In a televised debate it held on June 3 1975, students approved the motion 'This House would say "Yes" to Europe' by 493 votes to 92. See David Walter, The Oxford Union: Playground of Power (London, 1984), 192-3.

${ }^{37}$ For a detailed discussion of BIE's campaign tactics and how they responded to the NRC's arguments, see Butler and Kitzinger, The 1975 Referendum, 160-89. It certainly helped BIE that they had the support of all the daily national newspapers, except for the Morning Star.

${ }^{38}$ PA, BIE/18/23, 'Students for a United Europe, Enoch Powell Says The Common Market Will Destroy British Sovereignty'.
} 
young adults in an open-top car with one sat on the bonnet, suggesting to voters particularly those who held no firm opinions about the Community - that Europe had much to offer the younger generation. Little indication was given as to how this was the case though. Another set of posters featured a series of sketches beneath the slogan 'Keep Britain in Europe' and included images such as a young woman sunbathing and a mother duck feeding her young, the message from these seemingly being that membership of the Community was associated with a bright future. ${ }^{39}$

Overall cross-party youth groups' radicalism and optimism was noticeable in their literature. However, it was combined with a dose of pragmatism and, in some cases, apolitical justifications for continued EEC membership. One explanation for these characteristics is the concern of senior BIE campaign members about certain messages youth groups wished to promote. Indeed, they vetted the material of cross-party groups and were not immune from refusing its publication. ${ }^{40}$ For example, BIE rejected an SUEdesigned poster bearing the tongue-in-cheek slogan 'When the Queen is German and the Duke is Greek, aren't we all Europeans at heart?'. ${ }^{41}$ Such a provocative design would undoubtedly have proven controversial were it to have been mass-produced. Nevertheless,

\footnotetext{
${ }^{39} \mathrm{PA}, \mathrm{BIE} / 18 / 23$. The senior BIE campaign also had an apolitical aspect to it with posters promoting sportsmen and women, musicians, actors and actresses who backed membership. See Goodhart, Full-Hearted Consent, 166-8 and Saunders, Yes to Europe!, 107-8.

40 PA, BIE/1/39, 'Literature Production Group notes on meeting held Monday 7 April' and BIE/27/2, 'Minutes of Youth Steering Group Meeting, Monday 12 May'.

${ }^{41}$ Author interview with Piers Gardener, 3 August 2012.
} 
refusing to allow its use strengthens the view that Britain in Europe ran a conservative campaign concerned primarily with maintaining its healthy opinion poll lead. ${ }^{42}$

It could also be the case that cross-party groups' pragmatism stemmed from a recognition that they needed to target undecided, less engaged young voters. Indeed, young adults were demonstrably 'cooler' towards the subject they were being consulted about, a fact BIE were aware of. ${ }^{43}$ Results of the May 1975 Eurobarometer study, undertaken on behalf of the European Commission, further emphasise their apathetic attitudes. ${ }^{44}$ When asked if they felt membership of the Common Market was a good or bad thing for Britain, forty-two per cent of fifteen- to thirty-four years olds said it was a good thing, compared to forty-seven per cent overall, with a slightly greater proportion of young adults (twenty-five per cent against nineteen per cent overall) saying it was neither good nor bad..$^{45}$ They also demonstrated greater indifference towards the idea of the 'unification of Europe'. ${ }^{46}$ More specifically, when asked if six different policy areas would be better dealt with by combined action through the Common Market or by actions of the British government independently of other countries, for each item a majority of fifteen to thirty-

\footnotetext{
42 In early March 1975 the 'Yes' campaign had established a sixteen-percentage-point lead, which grew to thirty-points by the beginning of May. See Butler and Kitzinger, The 1975 Referendum, 250.

${ }^{43}$ Goodhart, Full-Hearted Consent, 165.

${ }^{44}$ Commission of the European Communities, Brussels: Eurobarometer 3, May 1975. Helene Riffault, Faits et Opinions, Paris [Producer]; GESIS, Cologne [Publisher]: ZA0987, dataset version 1.0.1, doi:10.4232/1.10855. The figures quoted relate to the United Kingdom and are based on the author's own calculations.

${ }^{45}$ Among fifteen- to thirty-four-year olds, a fifth considered membership a bad thing, one percentage point lower than the figure for the total sample.

${ }^{46}$ Forty-two per cent of young adults agreed with this aim, while twenty-seven per cent reported they felt indifferent. This compared to half of the overall sample who agreed and nineteen per cent who were indifferent. Young adults were no more likely to be against this idea.
} 
four year-olds answered 'action by the Community'. However, such preferences for European action were no greater than among the total UK population. ${ }^{47}$

Even though they did not chime with the views of the average young adult in Britain, space therefore existed for party-political organisations to outline more radical arguments. In the case of Young European Left (YEL), a group within the Labour Party, and, in particular, Radical Youth for Europe (RYE), the Young Liberals' referendum campaign vehicle, such visions were prominent.

\section{Party-political youth groups}

\section{Conservative Party youth groups}

However, the Federation of Conservative Students (FCS) and Young Conservatives - both strongly in favour of membership - were less willing to make public their calls for deeper integration. Instead, such arguments were largely limited to internal policy documents and, hinting at their activists' loyalty towards their party elders, their campaign material mostly toed the pragmatic line put forward in the main Conservative Party literature. ${ }^{48}$

The Conservatives largely united behind the pro-European cause in $1975 .{ }^{49}$ However, aside from Edward Heath, it is questionable as to how deeply pro-Common Market sentiment ran within party ranks. Indeed, when opening their campaign in April 1975, new

\footnotetext{
${ }^{47}$ This question asked about the problems of fighting inflation; engaging in diplomacy with the two superpowers; protecting the environment and tackling pollution; reducing regional disparities; implementing a policy on energy supplies; and modernising agriculture.

${ }^{48}$ Timothy Evans, Conservative Radicalism: A Sociology of Conservative Party Youth Structures and Libertarianism, 1970-1992 (Providence, Rhode Island, 1996), 17; Holroyd-Doveton, Young Conservatives, 74-5. ${ }^{49}$ N.J. Crowson, The Conservative Party and European Integration Since 1945: At the Heart of Europe? (London, 2007), 40-4.
} 
leader Margaret Thatcher's speech to the Conservative Group for Europe was notable for its pragmatic tone. Notably, Thatcher repeated on five occasions the mantra '[i]t is surely common sense...' when introducing her concluding arguments. ${ }^{50}$ Rather than issuing a manifesto, the party produced a series of single-page leaflets on a variety of EEC-related topics. Certain documents were targeted at specific areas of the country, with those for Scotland and Wales emphasising how membership benefited local industries. ${ }^{51}$ Meanwhile, issue-specific leaflets dealt with topics including 'Industry and the EEC', 'Agriculture, fishing and the EEC' and 'The EEC and the cost of living', and emphasised how Britain benefited from the security of food supply membership provided and the guaranteed EEC trading market. The effects of membership on Britain's sovereignty were also explained in a matter of fact manner to justify the decision to 'pool' decision-making power, while Britain's veto was noted. Proposed advances in integration were mentioned briefly. Yet it was clarified that Britain was under no obligation to take part in schemes including economic and monetary union. ${ }^{52}$ Collectively, the leaflets gave the impression that remaining a member was necessary for Britain and its ability to prosper in the future. Additionally, they suggested that being part of the EEC did not threaten the nation's political culture and traditions.

Similar messages were delivered by the Conservatives' youth organisations, albeit in a bolder fashion. A Young Conservatives leaflet was emphatic in its assertion that pooling sovereignty within the EEC benefited Britain, arguing that: '[w]e then gain in real power

\footnotetext{
${ }^{50}$ Margaret Thatcher, 'Speech to Conservative Group for Europe (opening Conservative referendum campaign)', 16 April 1975, online at Margaret Thatcher Foundation:

http://www.margaretthatcher.org/document/102675 (last accessed 8 August 2018).

51 PA, BIE/14/2, 'Conservative Party, Scotland and the EEC' and 'Conservative Party, Wales and the EEC'.

52 PA, BIE/14/2. See for example, 'Conservative Party, Sovereignty and the EEC', 'Conservative Party, Parliament and the EEC' and 'Conservative Party, Some key questions answered'.
} 
rather than paper power. ${ }^{53}$ Other reasons to remain a member included in the document centred around economic and political arguments reflecting those put forward in the party's main literature. FCS, meanwhile, produced five four-page campaign leaflets, only one of which could be claimed to have promoted a radical vision. ${ }^{54}$ Their general slogan - 'We've got to keep in to move on' - implied the benefits of membership would be reaped in the future. Yet the content of FCS's leaflets largely dealt with advantages Britain already enjoyed, while also warning about the consequences of withdrawal. Their first leaflet set out general reasons for supporting membership. Though FCS saw the Community as 'a potential political unit sharing a common culture', the remainder of their arguments ventured no further than highlighting the economic and security gains from being within the EEC and the lack of rational alternatives. ${ }^{55}$ Another leaflet was devoted to the issue of jobs, claiming that thousands would be at risk should Britain withdraw, and the financial support the Community's Regional and Social funds provided to the UK ${ }^{56} \mathrm{~A}$ third publication focused on developing countries. 'Outside the Community', FCS contended, 'an impoverished Britain would have only a modest role to play in helping the Third World', whereas as a member Britain played a key part 'in the Community's radical and progressive approach' towards these nations. ${ }^{57}$ In FCS's lone leaflet presenting an idealistic vision, they argued that the Community needed to work 'for the realities of today and the ideals of tomorrow'. They

\footnotetext{
53 PA, BIE/14/2, 'Young Conservatives, Keep Britain in Europe. DON'T PULL OUT'.

${ }^{54}$ Leaflets produced are listed in Alastair Everitt's bibliographical guide to the referendum. See Alastair Everitt, Britain and Europe during 1975 - Year of the Referendum: A Bibliographical Guide (Brighton, 1976), 33. Only four of the five leaflets could be traced during research for this article.

${ }^{55}$ University of Warwick, Modern Records Centre, MSS.21/397 'Federation of Conservative Students, We've got to keep in - to move on'.

${ }^{56}$ University of Warwick, MRC, MSS.21/396, 'Federation of Conservative Students, Jobs depend on Europe'.

${ }^{57}$ LSE/Coll Misc/0876, 'Federation of Conservative Students, Europe helps the world'.
} 
made clear their support for a federalist Europe too: direct elections to the European Parliament were seen as necessary, while a political union was called for in which environmental, education, social and labour policies would be devolved to the level where they could be dealt with best. ${ }^{58}$

The influence of their relationship with the party leadership appeared evident from the tone of the Conservative youth groups' literature, especially when compared to that included in internal communications, where they made a far more idealistic case for membership. The February 1975 edition of Tomorrow, the Young Conservative movement's newspaper, led with a rallying call to its membership to fight for a matter that had provided 'the most emotional and moving experience' when in 1971 they had backed Prime Minister Heath's push for entry. In a front-page editorial headlined 'In ... or Bust', members were implored to show 'characteristics of idealism, dedication and commitment' in the impending campaign and to forego partisan politics by joining cross-party efforts. Furthermore, the editorial mentioned the group's 'endorsement of the need for greater European unity as a lever for the speedy development of the Community'. Another article called for greater cultural exchanges within Europe 'to encourage European idealism'.${ }^{59}$ Meanwhile, the group's Chairman Tony Kerpel authored a pamphlet dealing with foreign policy entitled 'Britain's Role Restored'. Kerpel argued for the development of 'stronger links and mechanisms to unify foreign policy in Europe', with this being seen as particularly important

\footnotetext{
58 University of Warwick, MRC, MSS.21/398, 'Federation of Conservative Students, Together or alone?'.

${ }^{59}$ Young Conservatives, Tomorrow, February 1975. The newspaper's former editor Mike Rouse kindly supplied a photocopy of this edition.
} 
to assist developing countries. ${ }^{60}$ Minutes from Young Conservative meetings shortly after the referendum also offer deeper insights into their leadership's true opinions regarding Europe. Though they had been opposed to the concept of a referendum, certain Committee members wished to continue the campaign 'in a new guise' by initiating a 'European Twinning Scheme' with their ideological equivalents elsewhere in the EEC. They hoped too that the Conservative Party would subsequently 'fight for direct elections to the European Parliament' ${ }^{61}$

As with the Young Conservatives, FCS relegated their boldest ideas to internal documents. A policy paper titled 'The Foundations of Alignment', authored by Scott Hamilton, an FCS committee member, assessed the possibilities of centre-right parties across western Europe forming a European political party. From this he foresaw an opportunity to establish 'a proper-functioning system of democracy within Europe'. Hamilton argued that because of the greater ideological agreement between national parties on the left, an 'alignment of existing national [centre-right] parties' in Europe was essential. He was optimistic about the possibilities, identifying several policy areas where common ground existed, while also making the case that the parties shared views on forming an 'economic and monetary union, to be followed by some form of political union' ${ }^{62}$

\footnotetext{
${ }^{60}$ Oxford, Bodleian Library, Conservative Party Archive, PUB/90/22, 'Young Conservatives Key Policy Statement: Britain's Role Restored', 1975.

${ }^{61}$ Oxford, Bodleian Library, Conservative Party Archive, CCO/506/19/7, 'Young Conservatives Management Committee Meeting', 28 June 1975 and 'Young Conservatives Advisory Committee Meeting', 28 June 1975. ${ }^{62}$ British Library, General Reference Collection, WP.A.84/563, Scott Hamilton, The Foundations of Alignment of the European Centre-Right (London, January 1975).
} 
Despite the idealism expressed internally, the restraint that the Young Conservatives and FCS demonstrated in their publicly available literature was notable for multiple reasons. It suggests that they were the youth groups most committed to embracing cross-party efforts, something the Young Conservatives' leadership had been keen to promote. ${ }^{63} \mathrm{It}$ could also be seen to reflect the weaker politicisation of many of their members. ${ }^{64}$ Throughout the post-war period, the Conservatives boasted by far the largest youth organisations of the three main parties. While membership had declined by 1975, according to BIE records, the Young Conservatives still had around 30,000 members, with FCS possessing half as many. ${ }^{65}$ For such a large movement, it is likely that the core activist base represented only a small minority. In addition, their arguments corresponded with the tradition of Conservative youth groups not wishing to rock the party boat. ${ }^{66}$ It may have been of benefit that Heath, still a popular figure with his party's youth, was one of the BIE campaign's figureheads. Yet foreign policy issues had rarely been a point of conflict with the senior party anyway. ${ }^{67}$ However, such harmony did not exist within the Labour Party.

\section{Young European Left}

63 Oxford, Bodleian Library, Conservative Party Archive, CCO/506/19/7, 'Minutes of Meeting of the Young Conservatives Management Committee', 14 December 1974.

${ }^{64}$ Lawrence Black, 'The Lost World of Young Conservatism', The Historical Journai, 51, 4 (2008), 1023.

65 PA, BIE/1/83, 'Memo from Tom Spencer to Sir Con O’Neill, “The Plain Man's Guide”' 19 February 1975. In comparison, it is estimated that the Labour Party boasted around 10,500 youth and student members. See Matthew Lamb, 'Young Conservatives, Young Socialists and the Great Youth Abstention: Youth Participation and Non-Participation in Political Parties', PhD thesis, University of Birmingham, 2003.

${ }^{66}$ Layton-Henry, 'The Young Conservatives', 155-6. The referendum arrived just before a key juncture in the history of FCS, which developed a strong 'libertarian streak' in the late 1970s. See Evans, Conservative Radicalism, 18-9.

${ }^{67}$ Holroyd-Doveton, Young Conservatives, 194-8. Issues such as Rhodesia did lead to divisions within the Young Conservatives, but according to Holroyd-Doveton these merely reflected those in the party at large. 
Young European Left found themselves battling against the majority will of the Labour Party membership and its primary youth organisation, the Young Socialists, which both favoured withdrawal. However, YEL, which comprised a small group of individuals within the party, campaigned strongly for continued membership. ${ }^{68}$ Moreover, their case, which sought to promote 'radical socialist policies for a Labour Government to pursue within a European context', differed markedly to the arguments made by the party's pro-Marketeers. ${ }^{69}$

Unsurprisingly, the main Labour Campaign for Britain in Europe focused much attention on the government's renegotiation, claiming that Prime Minister Harold Wilson and Foreign Secretary James Callaghan had been successful in securing a deal in tune with the party's interests. ${ }^{70} \mathrm{~A}$ more detailed leaflet debunked anti-Marketeer arguments, within which the case for membership was made for four reasons. Firstly, it was argued that Britain should remain a member simply because 'it is Labour policy'. Additional reasons claimed that Britain's bargaining power would be weakened outside the EEC; that the Community Social Fund improved living and working conditions in Britain; and that the renegotiation would reduce Britain's budgetary contribution. Buried at the bottom was a token idealistic argument. Headed 'The Wider Vision', the document's authors reasoned that Britain and its fellow members, five of which had 'socialist governments', could build 'a socialist Community' ${ }^{71}$ However, this concept was not expanded on. Other literature was aimed at workers and trades unionists. But this again failed to clarify what 'a socialist Europe'

\footnotetext{
${ }^{68}$ PA, BIE/1/83, 'Memo from Tom Spencer to Sir Con O’Neill, “The Plain Man's Guide"' 19 February 1975.

69 University of Warwick, Modern Records Centre, MSS.21/399, 'Young European Left: recruiting leaflet'.

70 PA, BIE/15/1, 'Labour's Case for Europe'. The leaflet's entire back-page was devoted to the renegotiations.

${ }^{71} \mathrm{PA}, \mathrm{BIE} / 15 / 2$, 'Labour Campaign for Britain in Europe, Say "YES" to Europe'.
} 
entailed. Instead, facts about how specific industries benefited from an expanded home market, better employment protections, grants and subsidies dominated. ${ }^{72}$

In contrast, YEL's strong ideological position was made clear when the group published a pamphlet regarding the Labour Programme 1973 and Europe. The Programme committed Labour to establish a state investment arm and nationalise numerous industries, and was spearheaded by the faction on Labour's left, many of whom, including Tony Benn, were the party's loudest cheerleaders for leaving the EEC. ${ }^{73}$ While stating they agreed with the Programme's economic aims, YEL accused Labour anti-Marketeers of narrow-minded arrogance, arguing that by favouring withdrawal they disregarded the left's internationalism. ${ }^{74}$ Instead, YEL believed that the Programme could be compatible with membership, stating:

... on some issues the Community is neutral - neither preventing nor encouraging the growth of socialist policies, while in other areas the Community as a whole has been more progressive than us. ${ }^{75}$

Dismissing concerns that the EEC was a means to advance laissez-faire capitalism, its authors cited existing government investment bodies in Italy, France and West Germany as evidence that the Community was no threat to plans for public ownership. Further, through

\footnotetext{
${ }^{72} \mathrm{PA}, \mathrm{BIE} / 15 / 2$, See for example 'Labour Campaign for Britain in Europe, Textile Workers Say - "We're better off in Europe"'.

${ }^{73}$ Stuart Holland, 'The Industrial Strategy', in Anthony Seldon and Kevin Hickson (eds), New Labour, Old Labour: the Wilson and Callaghan Governments, $1974-79$ (London, 2004), 297-9.

${ }^{74}$ PA, BIE/15/71, 'Young European Left Press Release: YEL Accuse Anti-Marketeers of Arrogance', 30 October 1974.

${ }^{75}$ PA, BIE/15/71, 'Young European Left, Labour Programme and Europe', Summer 1974.
} 
proposals for a Common Industrial Policy and Regional Fund, YEL insisted that the EEC saw the 'key role exercised by governments in economic affairs'. YEL also claimed that members of the European Commission and socialists around Europe desired the strengthening of workers' rights, industrial democracy and regulations relating to living and working conditions. The document's conclusion further elaborated on their far-reaching vision, reasoning: '[t]he fundamental point is that democratic socialists in Britain, in collaboration with their socialist comrades on the Continent, can fight for a socialist society in Europe. ${ }^{76}$

A subsequent pamphlet released in spring 1975 made YEL's outline of a socialist Europe clearer. Foremost was the requirement for Labour to finally send representatives to the European Parliament and introduce direct elections. With a strengthened socialist presence, 'radical plans to ensure democratic control of multinational capital', regional and social policies and an improved aid programme could be implemented. ${ }^{77}$ This document also included greater criticism of anti-Marketeers, while pessimistic warnings about a 'No' vote with an anti-American bent were aired. Life outside the EEC would only serve to make 'Britain more dependent on the United States', end the chance of 'building a democratic socialist Europe' and prevent Britain from getting to grips with the threat multinational companies posed. ${ }^{78} \mathrm{~A}$ YEL broadsheet issued on university campuses during the campaign outlined more radical demands, including a call for cooperation between European socialist

\footnotetext{
${ }^{76}$ PA, BIE/15/71, 'Young European Left, Labour Programme and Europe', Summer 1974.

77 University of Warwick, Modern Records Centre, MSS.21/410, 'Young European Left, The Left, the Referendum, and the Future of Europe', Spring 1975.

${ }^{78}$ University of Warwick, Modern Records Centre, MSS.21/410, 'Young European Left, The Left, the Referendum, and the Future of Europe', Spring 1975. Such arguments replicated those held by the General and Municipal Workers' Union (GMWU), one of the few trades unions that supported continued membership. See PA, BIE/15/2, 'GMW Herald EEC Special', June 1975.
} 
parties 'to draw up a programme for a workers' Europe', public ownership at a European level - termed 'Europeanisation' - of multinational companies, a transfer in powers from the Commission to the European Parliament and enlargement to 'socialist' Greece and Portugal. ${ }^{79}$

In two shorter leaflets, YEL's idealism was muted. The first featured a cartoon of a pirate (representing Britain) cutting itself away from a ship called 'Socialist Europe', and set to fall into a sea of sharks emblazoned with Dollar signs. On the ship two characters dressed as stereotypical Frenchmen were attempting to save the pirate from falling into the sharkinfested waters. Though the cover was striking both in terms of the content of its argument and its pessimism, the reasons given inside promoting continued membership revolved around the EEC preserving jobs, safeguarding food supplies and providing Britain strength for a better future ${ }^{80} \mathrm{~A}$ second flyer, meanwhile, sought to discredit the antis' arguments, insisting that the Community was an outward-looking organisation and had the support of socialists. Those that would pay the price were Britain to withdraw would be working people. ${ }^{81}$

That YEL adopted a radical tone and demonstrated a commitment to socialist policies is unsurprising. Coupled with Labour's leftwards shift, in the early 1970s Militant, an avowedly Marxist grouping, had moved to assume control of the party's youth structure, which had recently been reformed to give the Young Socialists greater autonomy and

\footnotetext{
79 University of Warwick, Modern Records Centre, MSS.21/414, 'Young European Left: broadsheet', 1975.

80 PA, BIE/27/7, 'Young European Left, Our Community. Don't Cut Yourself Off. Vote Yes'.

${ }^{81}$ PA, BIE/27/7, 'Young European Left, Don't Be Fooled!'.
} 
representation on the party's National Executive Committee. ${ }^{82}$ Attempts to communicate with members can therefore be seen to have required YEL to embrace the economic prescriptions of the ascendant groups within the party. This was especially important when trying to sell continued EEC membership - a policy that a large swathe of influential party figures rejected. Whether their arguments reflected the true views of those involved with YEL was questionable though. Their leadership appeared to consist of individuals from the party's right, with the group's General Secretary Dick Newby ultimately defecting to the Social Democratic Party in 1981 . They were active too in cross-party groupings, including Julian Priestley who served as YEF President. Yet a clear ideological appeal had seemingly been the order of the day to try and persuade the party's base. The Young Liberals also took a purist approach towards their campaign. This, however, appeared less for defensive purposes than it was to seize a perceived opportunity.

\section{Radical Youth for Europe / Young Liberals}

Radical Youth for Europe, the Young Liberals' campaign arm, made very distinctive arguments in favour of continued membership. While in many areas their case was not too dissimilar from that of the senior Liberal Party, there were significant differences. Additionally, in an attempt to capitalise on divisions within the Labour Party, RYE also sought to position the Young Liberals as representing the views of the progressive, internationalist left.

\footnotetext{
82 Layton-Henry, 'Labour's Lost Youth', 302-4. For discussion of Militant's rise within the party's youth structures see Michael Crick, The March of Militant, Second edition (London, 1986), 60-8.
} 
The Liberal Party had committed to their 'Europe Campaign' in September 1974, starting early to achieve their professed goal of emphasising their vision for Europe. ${ }^{83}$ They were also the sole party to produce a manifesto, something which RYE replicated. The substance of both was similar with importance attached to promoting federalism, devolution, the transformation of the Community's institutions and deeper integration. Substantial differences of opinion existed over NATO though, while RYE made a more concerted effort to stress measures the EEC could take to check the powers of multinational firms.

The Liberal Party's manifesto provided far more radical arguments for continued membership than anything either Labour or the Conservatives produced. Heralding their campaign as 'a crusade', the party described their ultimate ideal as 'a democratically controlled union of nation states leading in the direction of a federal Europe'. This would see power distributed in a tiered structure, with regional assemblies empowered to check greater supranationalism. On top of the rational economic and political reasons for membership propagated by $\mathrm{BIE}$, the Liberals championed the need to transform the EEC. This included creating an economic and monetary union to stop member states pursuing 'competing economic policies'. Other reforms they supported included a common foreign policy aimed at 'reconciliation with ... Eastern Europe'; a common defence procurement policy for the EEC's NATO members; a strengthened, two-tiered European Parliament; a transfer of powers to the Commission so that it could function as the Community's 'executive'; and the scrapping of the national veto. The manifesto admitted that realising

${ }^{83} \mathrm{PA}, \mathrm{BIE} / 16 / 5$, 'Memorandum from Aza Pinney', post-referendum, undated. 
these goals required time. However, immediate policy harmonisation was seen as necessary to make it a reality. ${ }^{84}$

In comparison, the Young Liberals' manifesto began by sharply criticising the EEC's existing structure, labelling it 'a vast bureaucracy run in the interests of nine of the wealthy states ... and larger capitalist concerns'. Yet transformation rather than withdrawal was called for. Their primary concern was the democratisation of Europe's institutions, and detailed proposals for changes to the European Parliament, Commission and Council of Ministers corresponded with those set out in the main party manifesto. One additional desire was for greater industrial democracy to ensure a voice for 'both the members of an enterprise and the community ... in the running of enterprise'. Demonstrating the Young Liberals' 'libertarian socialist' credentials, membership was seen as the only safeguard against Britain becoming 'a non-participating subsidiary of the boardrooms of Detroit and Chicago' ${ }^{85}$ This anti-American attitude, shared with YEL, appeared again when discussing Europe's relationship with the wider world. Within the EEC Britain could 'free ourselves from the bondage of American influence', while an accommodation with Eastern Europe could only be achieved through 'the dissolution of both NATO and the Warsaw Pact' ${ }^{86}$ RYE campaign posters further emphasised their hostility towards the USA, one proclaiming: 'Yank\$ Out of Europe; Britain Stay In!'. ${ }^{87}$

\footnotetext{
84 LSE/Young Liberals/Box 3, 'Liberal Manifesto for Europe 1975'.

85 LSE/Young Liberals/Box 3, 'Stay in to move on - a Young Liberal case for Europe'. The Young Liberals at this time identified as 'Libertarian Socialists' and positioned themselves to the left of the parliamentary party. See Chris Cook, A Short History of the Liberal Party: The Road Back to Power, second edition (London, 2010$), 148$.

${ }^{86}$ LSE/Young Liberals/Box 3, 'Stay in to move on - a Young Liberal case for Europe'.

87 PA, BIE/16/3, 'Radical Youth for Europe, Yank\$ Out of Europe, Britain Stay In!'.
} 
Other distinct arguments sought to appeal to a student audience. Standardising education qualifications was suggested to achieve 'greater human mobility', while the National Union of Students and its President Charles Clarke were criticised for their attitudes towards sovereignty. Members of the pro-Marketeer establishment were not spared either. Labelled 'self-interested, economic determinists' for focusing on figures and prices to justify their case for membership, the Young Liberals highlighted that their pamphlet was free of statistics, relying instead on their vision for the EEC to persuade voters. $^{88}$

One other apparent campaign aim was to paint the Young Liberals as the true torchbearers of the 'progressive' left. A feature written by RYE chairman Simon Hebditch for a special edition of The Liberator newspaper demonstrated this. Hebditch derided the 'authoritarian Left' within Labour who desired Britain's withdrawal for 'nationalist' reasons. Using the arguments of political theorist Tom Nairn to support his critique, Hebditch reasoned that the Labour left had cast aside their internationalism and that the Young Liberals were the lone outward-looking group on that side of the ideological spectrum prepared to tackle capitalist concerns within Europe. ${ }^{89}$

Compared with the arguments put forward by Conservative and Labour youth groups, there is no doubting that the Young Liberals proposed more visionary arguments. Certain proposals including democratisation of the EEC's institutions and the view that membership provided Britain the opportunity to challenge the power of multinationals

\footnotetext{
${ }^{88}$ LSE/Young Liberals/Box 3, 'Stay in to move on - a Young Liberal case for Europe'.

${ }^{89}$ British Library, General Reference Collection, P.703/224, 'Young Liberals, The Liberator', May 1975. Writing in 1973, Nairn criticised the 'National' Marxism of Labour's anti-Marketeers. See Tom Nairn, The Left Against Europe (Harmondsworth, Middlesex, 1973), 88-91.
} 
were shared. Yet the Young Conservatives, FCS and YEL did not match the sustained radicalism of their Liberal contemporaries. This can partly be explained by the fact their campaign was organised through RYE, a small band of activists..$^{90}$ It also fits with their unease at fighting a cross-party campaign. ${ }^{91}$ Party leader Jeremy Thorpe, fresh from exploring the possibility of taking the Liberals into a coalition government in 1974, seemed comfortable campaigning across party lines. ${ }^{92}$ Yet, the Young Liberals appeared to be the most reluctant of the party-political youth groups to do so. ${ }^{93}$

Intriguingly though, when it came to proposals for the ways in which the Community should develop, there were few differences between the Young Liberals and the arguments of the main Liberal Party. This was in line with the general policy stances that the Young Liberals and their superiors took at the time. ${ }^{94}$ However, where they did diverge, the differences were significant. For the Young Liberals, EEC membership was a means of undermining NATO and reducing the United States' influence in European affairs, while their left-wing economic credentials were emphasised too. That the Young Liberals were allowed to proceed with such a radical approach is arguably partly explained by the significant role some of its key members played within the Liberal Party itself. Gordon Lishman was an

\footnotetext{
90 PA, BIE/1/83, 'Memo from Tom Spencer to Sir Con O’Neill, “The Plain Man's Guide”' 19 February 1975.

${ }^{91}$ RYE's disinterest was demonstrated by planning they carried out in 1974. Their Committee proposed to use a referendum campaign as a platform 'to embarrass the Labour Party, and to make it clear that it's not only capitalists who favour the EEC'. See LSE/Young Liberals/Box 5, 'Minutes of a RYE Committee Meeting held in Leicester on 27 July 1974'.

92 The Young Liberals were critical of the party leadership's openness to entering into a coalition. See David Dutton, A History of the Liberal Party since 1900, second edition (Basingstoke, Hampshire, 2013), 205-7.

${ }^{93}$ As mentioned earlier, RYE arranged their own 'Youth Aid' scheme, while Peter Hain dramatically withdrew as a speaker from BIE's Youth Rally.

${ }^{94}$ Ruth Fox, 'Young Liberal Influence and its Effects, 1970-74', Liberal Democrat History Group Newsletter, 14 (1997), 18.
} 
important figure in both camps, serving as RYE chairman until January 1975, while also working as Director of Policy Promotion for the senior party, which led him to author both the main Liberal and Young Liberal campaign guides. ${ }^{95}$ This reflected the Young Liberals' growing influence in the party too as their activists - Lishman chief among them - had recently spearheaded the adoption of 'Community Politics' tactics. ${ }^{96}$

\section{The Federalist}

One youth publication, appropriately titled The Federalist, did not seek to hide its thoughts about the radical direction its contributors desired integration to take. ${ }^{97}$ Nor did it hold back from criticising the main Britain in Europe campaign for avoiding the themes its authors felt were vital to discuss at a time of national weakness.

First published in 1973 with editions in May, to coincide with the Congress of Europe in London, and November, following the onset of the OPEC oil crisis and the EEC member nations' failure to coordinate their response, the magazine was resurrected in May $1975 .{ }^{98}$ Four issues, aiming to present the 'long term aspects of the case for a united federal Europe' from the perspective of 'a board of young federalists of all three political parties and none', were released during the campaign. ${ }^{99}$ No direct affiliation with BIE's youth arm was alluded to. However, Butler and Kitzinger mention that its producers were 'a few dissident young

\footnotetext{
95 PA, BIE/16/5, 'Report from the Director of Policy Promotion', 5 April 1975.

${ }^{96}$ Cook, A Short History of the Liberal Party, 149-51. This occurred in spite of the problems the Young Liberals had caused the party leadership as a result of their high-profile, disruptive anti-Apartheid protests. ${ }^{97}$ PA, BIE/27/8 and British Library, General Reference Collection, P.703/219. Three of the four campaign editions are available at the Parliamentary Archives, while the other is available in the British Library. ${ }^{98}$ For issues one and two see British Library, General Reference Collection, P.703/219, 'The Federalist'. $99 \mathrm{PA}, \mathrm{BIE} / 27 / 8$. This message was printed beneath the contents on the second page of each issue.
} 
Europeans, some actually working within the BIE headquarters' ${ }^{100}$ Documentary evidence helps make this clear.

Out of their sense of frustration at their superiors' campaign approach, BIE's Youth Steering Group felt it necessary to publish the magazine. BIE funds were not used to finance it though. Instead, money was obtained from the European Movement. ${ }^{101}$ The Economist correspondent Andrew Neil served as The Federalist's editor, while the identities of those writing articles were anonymised. Content was produced and its editorial slant determined by members of the Youth Steering Group, who met regularly at the Waldorf Hotel in London - BIE's base for its own press operations.

Although sales were not high, the magazine's remarkable content shines a clear light on how its contributors viewed European integration and the contemporary state of British politics. ${ }^{102}$ Combined with the circumstances in which the magazine was published and the identity of its authors, this suggests that its intended audience was as much those running the senior BIE campaign as it was members of the public interested in the issues discussed. Indeed, a consistent feature was a scathing attitude towards not only the anti-Market campaign, but also that seeking to keep Britain a member. As often as the likes of Powell, Benn and the NUS were ridiculed for their 'extremist', 'fictitious', or 'racialist' arguments and alleged underhand campaign tactics, an equal amount of opprobrium was directed at

\footnotetext{
100 Butler and Kitzinger, The 1975 Referendum, 173.

101 PA, BIE/27/3/26, 'Letter from Young European Federalists - Memorandum on the financing of the “Federalist Magazine"”, 13 July 1975.

102 PA, BIE 27/3/26, 'Letter from Tom Spencer to Ota Adler', 9 July 1975' The Federalist's final accounts show that $£ 480$ was received for sales, with copies sold for $10 p$ each, while Spencer reported that 500 copies of each issue were still available.
} 
BIE's leaders. ${ }^{103}$ This is vitally significant in highlighting the extent of the disaffection those in charge of organising the youth campaign felt towards their superiors.

The youth campaigners commonly accused those they were supposedly cooperating with of being overly complacent. They fired a warning shot in the editorial of The Federalist's first referendum edition, expressing fear that the result was not a done deal because the anti-Marketeers' emotive arguments were more likely to appeal than the stale Yes campaign. ${ }^{104}$ Two weeks later, the publication lambasted 'the subterranean profile and soporific content of the pro-European campaign', with concern voiced that the 'smug complacency of the European elite in Britain' could lead to a repeat of Norway's rejection of membership in a referendum in August 1972. ${ }^{105}$ Other criticisms revolved around the volume of bureaucracy within the organisation, which conspired to make the issue 'less relevant to the man in the street'. Meanwhile, BIE's leaflet was branded 'comatose' and their first television broadcast criticised for failing to play on voters' emotions. ${ }^{106}$

Yet the most telling sign that there existed a lack of unity between the youth and senior campaigns were The Federalist's comment articles, which outlined the authors' visions of a federal Europe and brought together policies advocated by YEF, SUE and the

\footnotetext{
${ }^{103}$ PA, BIE/27/8. See 'Smear-Froth forgets', The Federalist, issue three, 1 May 1975; 'Lies, damned lies and antiEurope propaganda', The Federalist, issue four, 17 May 1975; and 'Float like a butterfly sting like a bee', The Federalist, issue six, 31 May 1975' Also see British Library, General Reference Collection, P.703/219, 'Cultivated Crank', The Federalist, issue five, 24 May 1975 for an article attacking Peter Shore.

${ }^{104}$ PA, BIE/27/8, 'All over, bar the losing', The Federalist, issue three, 1 May 1975.

105 PA, BIE/27/8, 'Three Snores for Europe', The Federalist, issue four, 17 May 1975. In the August 1972 referendum in Norway, $53.5 \%$ voted against their country joining the EEC.

106 PA, BIE/27/8, 'Pass the Horlicks', The Federalist, issue three, 1 May 1975 and 'We can't go there', The Federalist, issue six, 31 May 1975. See also British Library, General Reference Collection, P.703/219, 'Flow charts for Europe', The Federalist, issue five, 24 May 1975.
} 
party youth groups. These discussed proposals for altering the distribution of decisionmaking powers within the EEC and put forward the case for political and monetary integration.

In the first referendum edition it was posited that, in light of the USA's retreat from South East Asia and the perceived threat that posed to NATO's future, developing a common foreign and defence policy should become an 'immediate concern' for the EEC. Furthermore, they concluded that if Britain was to retain any influence in the world, it had to remain a Community member. ${ }^{107}$ The subsequent issue dealt more with campaign proceedings and the lessons of the Norwegian referendum. But The Federalist's stance on how power should be distributed within the EEC was made explicit in the editorial:

... we can enhance the sovereignty of people ... if we stay in the Community and work towards the creation of a federal Europe, run by a directly-elected European Parliament with power over the executive institutions and assuming responsibility for key areas of policy - defence, energy, foreign affairs and general economic management. That is the theme which should dominate the debate. ${ }^{108}$

Two weeks before polling day, The Federalist's front page carried the title 'Birth of a Nation'. The cover depicted a chick coloured with the design of the flag of Europe breaking out of an egg labelled 'EU'. The connotations were obvious: a European nation state was the authors' desired goal. Outlining how such a state would be governed, the editorial called for the 'development of an effective democracy at three levels - in a directly elected European parliament, in the national parliaments and in regional parliaments' - because the existing

\footnotetext{
107 PA, BIE/27/8, 'NATO: the crumbling deterrent', The Federalist, issue three, 1 May 1975.

108 PA, BIE/27/8, 'Three snores for Europe', The Federalist, issue four, 17 May 1975.
} 
political units were 'at the same time too big and too small' ${ }^{109}$ In order to cope with an elected Parliament, it was argued that the various competences of the EEC's institutions would have to be altered. The Parliament would gain control over budgetary matters and appoint the Commission, which in turn would function as a European Cabinet. Finally, the Council of Ministers would include representatives from regional as well as national governments and serve as a European Senate. ${ }^{110}$

The magazine's final edition then dealt with devolution and how regional governments - the lowest tier of governance proposed - would function. This may seem an issue unconnected with the referendum, and was unlikely to convince those most in favour of devolution in Britain given that both the Scottish National Party and Plaid Cymru were in favour of withdrawal. ${ }^{111}$ But, according to The Federalist, 'a parallel transfer of responsibilities to regional government' was 'what a "yes" vote is all about'. Arguing that the EEC needed to adopt a more radical regional policy, the case for an economic and monetary union, which would bring about a 'more generous redistribution of wealth', was also made. ${ }^{112}$

As idealistic as such views were, another factor underpinning the publication's staunch federalist views was the belief that the nation state could no longer solve the issues of the day by itself. In Britain this was hampered by the failure of the political establishment

\footnotetext{
${ }^{109}$ British Library, General Reference Collection, P.703/219, 'The honest answer', The Federalist, issue five, 24 May 1975.

${ }^{110}$ British Library, General Reference Collection, P.703/219, 'Future parties', The Federalist, issue five, 24 May 1975.

${ }^{111}$ For discussion of the positions the Nationalist parties adopted, see Butler and Kitzinger, The 1975 Referendum, 150-5.

112 PA, BIE/27/8, 'Pull the trigger', The Federalist, issue six, 31 May 1975.
} 
- or 'the Wilson-Thatcher-Thorpe nexus' as it was pejoratively labelled - to tackle these problems. ${ }^{113}$ This view was not uncommon among the wider electorate. Perceptions that the Conservative and Labour parties were unable to effectively govern had helped result in a surge in support for the Liberal Party and greater success for the Scottish and Welsh national parties in the two general elections held in $1974 .{ }^{114}$ However for those involved with The Federalist, EEC membership was seen as the most likely salvation for Britain. Not only was this for pragmatic reasons. Instead, they took an overwhelmingly radical view of the Community, arguing that deeper integration was necessary to rescue Britain from the crisis in which it found itself.

\section{Conclusion}

Until now the contributions of student and youth groups towards the campaign to keep Britain in Europe in 1975 have been neglected. While noted for their federalist zeal and dissatisfaction with the way in which Britain in Europe ran its campaign, their often radical, idealistic views about European integration have not been sufficiently explored. But by examining the referendum campaign literature they produced, knowledge of the nature of the debate regarding Britain's place in Europe is greatly enhanced. Importantly, analysing youth groups' arguments for continued membership further exposes the myths that sovereignty and deeper integration were not discussed in the lead up to the 1975 referendum. More broadly, reviewing their contributions provides greater insight into the differing relationships between political youth groups and their party elders during the 1970s, as well as a detailed understanding of where they stood on a particular policy issue.

\footnotetext{
113 PA, BIE/27/8, 'Small is beautiful', The Federalist, issue six, 31 May 1975.

${ }^{114}$ Ivor Crewe, 'The Electorate: Partisan Dealignment Ten Years On', West European Politics, 6 (1983), 183-5.
} 
It is clear that the various youth groups participating in the 1975 referendum campaign saw integration as serving different purposes. Their arguments differed in content and tone too. Nevertheless, the groups examined in this article all shared a desire to see Britain not only remain a member of the EEC but contribute towards the deepening of competences held at Community-level. Prices, jobs and even peace appeared far less salient for youth campaigners, who instead adopted a more 'forward-looking rhetoric' commonly associated with young activists. ${ }^{115}$ They viewed European integration as a way of overcoming the unique challenges of the day, which the nation state alone could not tackle. Additionally, membership of the EEC was seen as a way of securing a better future for Britain, while bringing the peoples of Europe closer together. Again though, differences existed in the emphasis and prominence youth groups gave to these arguments, which - at least in the case of party-political youth groups - appeared to be partially influenced by their relationship with and the stance of their party superiors. It is striking too how much of the Community's development in subsequent years mirrored the structures and proposals youth groups put forward in $1975 .^{116}$

However, as contemporary survey evidence demonstrated, the views of these groups were not representative of the majority of young people in Britain regarding

\footnotetext{
${ }^{115}$ Philip Abrams and Alan Little, 'The Young Activist in British Politics', The British Journal of Sociology, 16, 4 (1965), 316-7.

${ }^{116}$ It is important to note that some of their proposals reflected discussions and developments taking place at a European level. The 1970 Werner Report set out proposals to establish an economic and monetary union; the member states were committed to hold elections to the European Parliament; and foreign policy coordination, conducted through the European Political Cooperation (EPC) mechanism, was in its infancy. Plans for greater cooperation in the fields of regional, environmental, social and energy policy, among others, had also been mooted. See Desmond Dinan, Europe Recast: A History of European Union (Basingstoke, 2004), 128-34, 142-55.
} 
European integration. Despite this inconvenient fact, it does beg the question as to whether or not greater publicity for youth groups' arguments and the adoption of a more optimistic, idealistic tone by the main Britain in Europe campaign in 1975 may potentially have been of long-term use to the pro-European cause in Britain. Given what was at stake as well as the salient issues of the day, it is unsurprising that BIE's leaders minimised the electorate's exposure to views about potential future developments in integration, let alone arguments in favour of continued membership that were expressed in a radical manner. But based on the referendum's eventual outcome, perhaps a less risk-averse approach would have been acceptable, even if it resulted in a reduced margin of victory.

Word count: 11,052 words 